\title{
Notícias do Departamento
}

\section{Defesas de Teses e Dissertações em 2006}

- $\quad$ No dia 08/03/2006, a DISSERTAÇÃO DE MESTRADO intitulada "Prefigurações de Hesíodo em Daniel: a correspondência entre o mito das cinco raças e o sonho da es-tátua de Nabucodonozor" do aluno SOARES, Dionísio Oliveira, candidato ao título de Mestre em Teologia.

- $\quad$ No dia 09/03/2006, a DISSERTAÇÃO DE MESTRADO intitulada "Os pergaminhos da Torá do Museu Nacional: crítica textual dos rolos referentes ao livro do Gênesis." do aluno ARAÚJO, Carlos Alberto Ribeiro de, candidato ao título de Mestre em Teologia.

- $\quad$ No dia 13/03/2006, a DISSERTAÇÃO DE MESTRADO intitulada "Entre Certezas e Desafios: Ética Sexual Católica e Concepção de Sexualidade Humana Hoje." da aluna TAVARES, Cássia Quelho, candidata ao título de Mestre em Teologia.

- $\quad$ No dia 13/03/2006, a DISSERTAÇÃO DE MESTRADO intitulada “A pessoa humana integrada e a opção por Jesus Cristo. Visão antropológica contida nas Cartas de En-rique de Ossó e sua relevância hoje." da aluna ROMIO, Rita, candidata ao título de Mestre em Teologia.

- $\quad$ No dia 15/03/2006, a DISSERTAÇÃO DE MESTRADO intitulada "Is 56,1-8. A visão acerca do estrangeiro na comunidade pós-exílica." do aluno UTRINI, Heitor Carlos Santos, candidato ao título de Mestre em Teologia.

- $\quad$ No dia 28/09/2006, a TESE DE DOUTORADO intitulada "Antropologia e Soteriologia: Concepção cristã de pessoa humana nos escritos teológicos de Juan Alfaro." do aluno SILVA, Luís Maurício Telles da, candidato ao título de Doutor em Teologia. 
- $\quad$ No dia 29/09/2006, a TESE DE DOUTORADO intitulada "Malaquias 3.13-21 no conjun-to dos Doze Profetas." do aluno FILHO, Paulo Severino da Silva, candidato ao título de Doutor em Teologia.

- $\quad$ No dia 11/12/2006, a DISSERTAÇÃO DE MESTRADO intitulada “A parábola dos vi-nhateiros homicidas de Mateus 21, 33-46 à luz das ressonâncias de Isaías 5, 1-7. “ do aluno ASSIS, Eliezer Alves de, candidato ao título de Mestre em Teologia.

- $\quad$ No dia 20/12/2006, a TESE DE DOUTORADO intitulada "O Iivro de Miquéias no con-junto dos Doze Profetas. Estudo Intertextual entre Mq 7,8-20 e os Chamados Peque-nos Profetas." da aluna SOUZA, Maria de Lourdes dos Santos, candidata ao título de Doutora em Teologia 